\title{
Pengaruh ekstrak teh hijau (Camellia sinensis) terhadap kadar malondialdehid (MDA) plasma dan kekuatan genggam tangan lanjut usia
}

Effect of green tea extract (Camellia sinensis) to plasma malondialdehyde (MDA) level and hand grip strength of elderly Fera Nofiartika ${ }^{1}$, Susetyowati ${ }^{2}$, I Dewa Putu Pramantara ${ }^{3}$, Lily Arsanti Lestari²

${ }^{1}$ Program Studi Ilmu Gizi, Fakultas Ilmu Kesehatan Universitas Respati Yogyakarta
${ }^{2}$ Departemen Gizi Kesehatan, Fakultas Kedokteran Universitas Gadjah Mada

2 Departemen Gizi Kesehatan, Fakultas Kedokteran Universitas Gadjah Mada
${ }^{3}$ Departemen Ilmu Penyakit Dalam, Rumah Sakit Umum Pusat Dr Sardjito

\begin{abstract}
Background: Prevalence of Indonesian elderly has now reached 7\%, which is considerably high. Physical performance is an important health status indicator in elderly. Declining of physical performance such as hand grip strength in elderly is related to oxidative stress. Furthermore, oxidative stress plays an important role on the decreasing of skeletal muscle function. Plama malondialdehyde (MDA) is a lipid peroxidation residue that is often used as an oxidative stress biomarker. Meanwhile, tea is the most widely drunk beverage after water. Green tea contains antioxidants that can reduce the damages caused by oxidative stress. Objective: To assess the effect of green tea extract (GTE) on plasma malondialdehyde level and hand grip strength of elderly. Method: This was a double blind experimental with pre-post test and control group. Fifty-seven elderly people from Balai Pelayanan Sosial Tresna Wredha (BPSTW) Abiyoso and Budi Luhur who met inclusion and exclusion criterias were divided into 2 groups. During 30 days, the first group was given 2 capsules of GTE a day ( $\pm 168 \mathrm{mg}$ katekin and $95 \mathrm{mg}$ Epigallocatechingallate (EGCG)) and the second group was given a placebo. MDA was measured by thiobarbituric acid (TBA) method and hand grip strength was measured by handgrip hand grip dynamometer. Results: There was a significant decreasing MDA $(p<0.05)$ in the GTE group, but not in the placebo group. There was also increasing handgrip strength in the GTE group but not in the placebo group. Conclusion: green tea extract can prevent increasing MDA and declining physical handgrip strength in elderly.
\end{abstract}

KEY WORDS: elderly; green tea; hand grip strength; malondialdehyde; physical performance

\begin{abstract}
ABSTRAK
Latar Belakang: Indonesia sudah masuk pada kelompok negara berstruktur tua, yaitu negara yang memiliki persentase penduduk lanjut usia (lansia) lebih dari tujuh persen. Performa fisik merupakan indikator status kesehatan yang sangat penting pada lansia. Penurunan performa fisik pada lansia, termasuk penurunan kekuatan genggam tangan, berkaitan dengan stres oksidatif karena radikal bebas. Stres oksidatif berperan penting pada terjadinya penurunan fungsi otot skeletal. Malondialdehid (MDA) adalah senyawa hasil peroksidasi lemak yang sering digunakan sebagai penanda terjadinya stress oksidatif. Teh adalah minuman yang paling banyak dikonsumsi di seluruh dunia setelah air putih. Teh hijau mengandung antioksidan yang dapat mengurangi kerusakan oksidatif. Tujuan: Mengetahui pengaruh pemberian ekstrak teh hijau terhadap kadar MDA plasma dan kekuatan genggam tangan lansia. Metode: Penelitian eksperimental menggunakan rancangan pretest dan posttest dengan kontrol serta double blind. Sebanyak 57 lansia dari BPSTW Abiyoso dan Budi Luhur yang memenuhi kriteria inklusi dan eksklusi kemudian dibagi dalam 2 kelompok perlakuan. Kelompok intervensi diberikan ekstrak teh hijau 2 kapsul sehari ( $\pm 168 \mathrm{mg}$ katekin dan $95 \mathrm{mg}$ EGCG) dan kelompok kontrol mendapat placebo selama 30 hari. Pengukuran MDA dilakukan dengan metode thiobarbituric acid (TBA) dan kekuatan genggam tangan diukur dengan handgrip dynamometer. Hasil: Diperoleh penurunan kadar MDA yang signifikan $(\mathrm{p}<0,05)$ pada kelompok yang mendapat ekstrak teh hijau. Namun, penurunan ini tidak berbeda dengan kelompok yang mendapat placebo. Terjadi kecenderungan peningkatan kekuatan genggam tangan pada kelompok yang mendapat ekstrak teh hijau, akan tetapi perubahan ini tidak berbeda signifikan dengan kelompok yang mendapat placebo. Simpulan: Pemberian ekstrak teh hijau terbukti mampu mencegah kenaikan MDA dan menghambat penurunan kekuatan genggam tangan pada lansia.
\end{abstract}

KATA KUNCI: lansia; teh hijau; kekuatan genggam tangan; malondialdehid; performa fisik

Korespondensi: Fera Nofiartika, Program Studi Ilmu Gizi, Fakultas Ilmu Kesehatan Universitas Respati Yogyakarta, Jl. Raya Tajem km 1,5 Maguwoharjo, Depok, Sleman, Yogyakarta, e-mail: fera.nofiartika@mail.ugm.ac.id 


\section{PENDAHULUAN}

Jumlah lansia di Indonesia pada tahun 2014 mencapai 20,24 juta jiwa yang setara dengan 8,03 persen dari seluruh penduduk (1). Persentase penduduk lansia yang telah mencapai angka di atas tujuh persen, menunjukkan bahwa Indonesia sudah mulai masuk ke kelompok negara berstruktur tua (ageing population). Lansia merupakan golongan yang rawan mengalami masalah kesehatan. Derajat kesehatan lansia saat ini juga masih rendah. Performa fisik dan kemampuan fisik merupakan indikator status kesehatan yang sangat penting pada lansia dan berkaitan erat dengan kualitas hidup. Penurunan performa fisik, aktivitas fisik, dan status gizi berkaitan dengan luka karena terjatuh, morbiditas, dan kematian $(2,3)$.

Kekuatan otot merupakan komponen performa fisik yang utama. Kekuatan otot menurun 12-15\% setelah usia 50 tahun dan menurun lebih banyak hingga 50\% pada lansia berusia lebih dari 80 tahun $(4,5)$. Kekuatan otot ekstremitas atas dan bawah sering dipakai untuk mengetahui performa fisik lansia secara umum. Kekuatan genggam tangan adalah indikator performa fisik yang dapat mengukur kekuatan otot ekstremitas atas dan bawah secara umum. Dewasa ini, beberapa peneliti menyatakan bahwa penurunan performa fisik pada lansia berkaitan dengan stres oksidatif karena radikal bebas (6). Stres oksidatif berperan penting pada terjadinya penurunan fungsi otot skeletal (7). Malondialdehid (MDA) adalah salah satu senyawa hasil peroksidasi lemak yang sering digunakan sebagai penanda terjadinya stres oksidatif (8).

Teh adalah minuman yang paling banyak dikonsumsi di seluruh dunia setelah air putih (9). Teh hijau adalah minuman yang mengandung antioksidan golongan polifenol berupa katekin, yaitu epigalokatekin galat (EGCg), epigalokatekin (EGC), epikatekin galat (ECg), dan epikatekin (EC) (10). Penelitian pada hewan coba dan orang sehat menunjukkan bahwa konsumsi teh hijau terbukti dapat menurunkan peroksidasi lipid berupa MDA (11-13). Teh hijau aman dikonsumsi lanjut usia karena memiliki toksisitas yang rendah (14).

Penelitian mengenai hubungan antioksidan pada kekuatan genggam tangan masih sangat terbatas. Sejauh ini, penelitian mengenai pengaruh antioksidan pada kekuatan genggam tangan banyak dilakukan pada atlet dan orang dewasa sehat. Penelitian mengenai hubungan antara asupan antioksidan dan vitamin terhadap kekuatan otot lansia pernah diteliti pada tahun 2004 (15). Hasil penelitian tersebut menunjukkan bahwa terdapat hubungan yang erat antara asupan antioksidan berupa vitamin $\mathrm{C}$ dan vitamin $\mathrm{E}$ terhadap kekuatan otot lansia. Meski demikian, hingga saat ini mekanisme antioksidan terhadap kekuatan genggam tangan lansia belum jelas. Oleh karena itu, perlu dilakukan penelitian ini dengan tujuan untuk mengetahui pengaruh pemberian ekstrak teh hijau terhadap kadar MDA plasma dan kekuatan genggam tangan lansia.

\section{BAHAN DAN METODE}

Desain penelitian ini adalah randomized control trial (RCT) menggunakan rancangan pre test dan post test serta double blind. Intervensi dilakukan selama 30 hari pada bulan September-Oktober 2015. Variabel bebas berupa kapsul yang berisi ekstrak teh hijau serta placebo dan variabel terikatnya berupa kadar MDA dan kekuatan genggam tangan. Subjek penelitian adalah lansia yang bertempat tinggal di Balai Pelayanan Sosial Tresna Werdha Balai Pelayanan Sosial Tresna Werdha (BPSTW) Abiyoso dan BPSTW Budi Luhur di Yogyakarta yang memenuhi kriteria inklusi dan eksklusi. Kriteria inklusi subjek antara lain responden bersedia menandatangani informed consent dan mampu berkomunikasi dengan baik. Kriteria eksklusi meliputi tidak dapat beraktivitas secara mandiri yang ditunjukkan dengan skor indeks barthel $<90$, mengalami demensia, dan gangguan jiwa yang dinyatakan melalui pemeriksaan psikiater BPSTW. Penelitian ini layak dilakukan berdasarkan surat keterangan kelaikan etik yang dikeluarkan oleh Fakultas Kedokteran Universitas Gadjah Mada (UGM) pada tahun 2015. Besar subjek penelitian ini ditentukan menggunakan rumus untuk penelitian eksperimental berdasarkan beda rata-rata dua populasi (16). Perhitungan ini menggunakan rumus dengan tingkat kepercayaan 95\% dan power $85 \%$ sehingga diperoleh 14 orang sebagai jumlah subjek minimal dalam setiap kelompoknya. Estimasi drop out 10\% sehingga besar subjek yang dibutuhkan pada penelitian ini minimal sebanyak 16 orang pada setiap kelompoknya. 
Kelompok pertama diberi kapsul berisi ekstrak teh hijau $2 \mathrm{x}$ sehari yang mengandung $\pm 168 \mathrm{mg}$ katekin dan 95 mg EGCG dalam setiap kapsulnya. Kelompok kedua adalah kelompok kontrol yang diberikan kapsul placebo 2x sehari yang berisi Saccharum lactis. Kapsul ekstrak teh hijau yang digunakan adalah kapsul ekstrak teh hijau komersial yang telah mendapat sertifikat Badan Pengawas Obat dan Makanan (BPOM) sedangkan kapsul placebo dibuat di Fakultas Farmasi UGM. Penelitian ini menggunakan double blind sehingga peneliti maupun subjek penelitian tidak mengetahui kapsul yang diberikan berisi ekstrak teh hijau atau placebo. Apoteker bertugas menyiapkan kapsul dan memegang kode kapsul. Apoteker menyerahkan kode kepada peneliti setelah penelitian berakhir. Kapsul diberikan kepada subjek penelitian setiap minggu. Pemantauan kesehatan dan efek samping dilakukan secara rutin dengan bekerja sama dengan tenaga kesehatan BPSTW. Kepatuhan mengonsumsi kapsul dilihat dari sisa kapsul pada akhir minggu. Subjek dinyatakan drop out jika kepatuhan konsumsi kapsul kurang dari $80 \%$, mengalami alergi, dan hospitalisasi oleh karena penyakit lain yang tidak berkaitan dengan perlakuan penelitian.

Pengukuran MDA dilakukan dengan metode thiobarbituric acid (TBA) di Laboratorium Biokimia Fakultas Kedokteran UGM. Pengambilan darah untuk pemeriksaan kadar MDA dilakukan pada pagi hari oleh perawat yang telah tersertifikasi melalui vena cubiti. Sebelum dilakukan pengambilan darah, subjek berpuasa selama 8 jam pada malam hari. Pengukuran kekuatan genggam tangan dilakukan menggunakan alat hand grip dynamometer dan dinyatakan dalam satuan kilogram $(\mathrm{kg})$. Lebih lanjut, asupan makan subjek termasuk konsumsi makanan sumber antioksidan seperti teh hitam dicatat menggunakan formulir recall 24 jam. Standar yang digunakan untuk menentukan kecukupan asupan yaitu berdasar angka kecukupan gizi (AKG) tahun 2013. Status gizi subjek ditentukan menggunakan indeks massa tubuh (IMT) dan Mini Nutritonal Asessment (MNA). Pengambilan data dibantu oleh enumerator dengan kualifikasi sarjana gizi.

Sebelum dilakukan analisis data, data diuji dahulu tingkat sebaran atau distribusi data menggunakan uji Saphiro-Wilk. Data yang terdistribusi normal diuji menggunakan paired-t-test untuk mengetahui perubahan kadar MDA dan kekuatan genggam tangan setelah pemberian ekstrak teh hijau dan placebo. Data yang tidak terdistribusi normal diuji menggunakan Wilcoxon signedrank tes (17). Uji independent t-test digunakan untuk mengetahui ada atau tidaknya perbedaan perubahan kadar MDA dan kekuatan genggam tangan pada perlakuan yang berbeda. Uji dikatakan berbeda signifikan jika nilai $\mathrm{p}<0,05$.

\section{HASIL}

\section{Karakteristik subjek penelitian}

Populasi penelitian sejumlah 135 lansia yang berasal dari BPSTW Abiyoso dan BPSTW Budi Luhur, tetapi hanya 61 lansia yang memenuhi kriteria sebagai subjek penelitian. Perjalanan jumlah subjek hingga akhir penelitian dapat dilihat pada Gambar 1.

Subjek penelitian ini adalah lansia yang dapat beraktivitas secara mandiri yang ditunjukkan dengan rerata indeks barthel sebesar 97,32 $\pm 3,4$ dan 97,75 $\pm 3,4$ pada kelompok perlakuan dan kelompok kontrol. Tabel 1 menunjukkan bahwa kedua kelompok memiliki karakterisktik subjek yang tidak berbeda $(\mathrm{p}>0,05)$.

Tabel 1. Karakteristik subjek penelitian

\begin{tabular}{lccccc}
\hline \multirow{2}{*}{$\begin{array}{l}\text { Karakteristik } \\
\text { subjek }\end{array}$} & \multicolumn{2}{c}{ Teh hijau } & \multicolumn{2}{c}{ Placebo } & \multirow{2}{*}{$\mathbf{p}$} \\
\cline { 2 - 4 } & $\mathbf{n}$ & $\mathbf{\%}$ & $\mathbf{n}$ & $\mathbf{\%}$ & \\
\hline Usia (tahun) & & & & & \\
$60-79$ & 21 & 75 & 20 & 69 & 0,612 \\
$\geq 80$ & 7 & 25 & 9 & 31 & \\
Jenis kelamin & & & & & \\
Laki-laki & 13 & 46 & 14 & 48 & 0,590 \\
Perempuan & 15 & 64 & 15 & 52 & \\
Status pernikahan & & & & & \\
Menikah & 2 & 7 & 5 & 17 & 0,408 \\
Duda/janda & 25 & 89 & 22 & 76 & \\
Tidak menikah & 1 & 4 & 2 & 7 & \\
Pendidikan & & & & & \\
Tidak sekolah & 11 & 40 & 10 & 34 & \\
SD & 9 & 32 & 7 & 24 & 0,605 \\
SMP & 4 & 14 & 5 & 17 & \\
SMA & 2 & 7 & 6 & 21 & \\
Akademi/sarjana & 2 & 7 & 1 & 4 & \\
Riwayat merokok & & & & & \\
Ya & 6 & 21 & 7 & 24 & 0,807 \\
Tidak & 22 & 79 & 22 & 76 & \\
\hline & & & & &
\end{tabular}




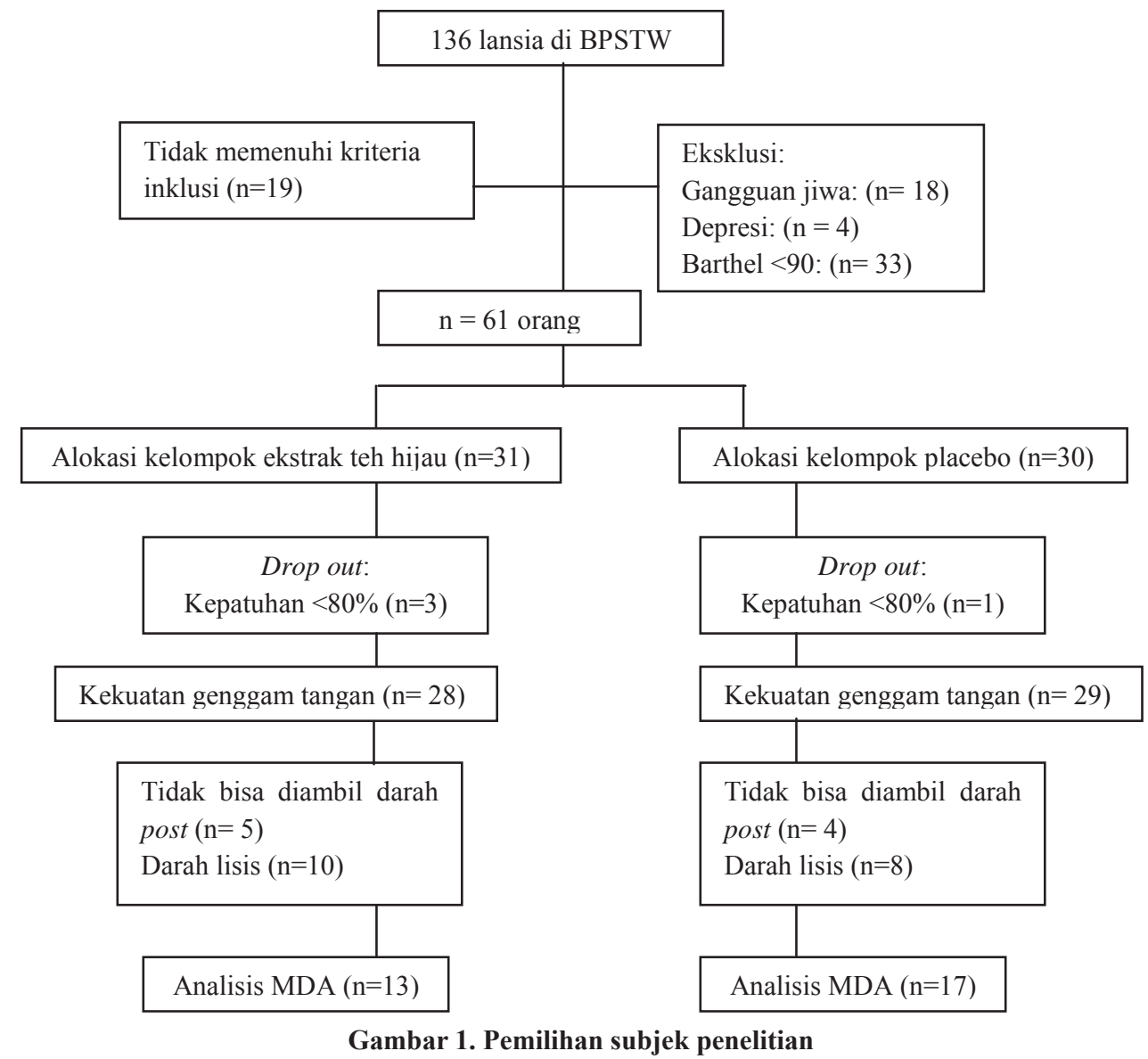

Berdasarkan pengukuran IMT dan MNA, sebagian besar subjek baik pada kelompok perlakuan maupun kelompok kontrol berstatus gizi baik. Data asupan makanan menunjukkan bahwa sebagian besar subjek penelitian kekurangan asupan energi, protein, dan vitamin C (Tabel 2). Berdasarkan AKG, kebutuhan energi lansia berusia 65-80 tahun untuk perempuan adalah 1.550 kkal dan 1.900 kkal untuk laki-laki sedangkan rerata asupan energi pada kedua kelompok sebesar 1.313 dan 1.195 kkal. Rata-rata asupan protein subjek pada kedua kelompok masih kurang dari $40 \mathrm{~g}$, padahal kebutuhan protein lansia berusia 65-80 tahun sebesar $56 \mathrm{~g}$ untuk perempuan dan $65 \mathrm{~g}$ untuk laki-laki. Asupan vitamin $\mathrm{C}$ pada kedua kelompok bahkan tidak mencapai setengah dari AKG 2013 yaitu hanya $31 \mathrm{mg}$ dan 33 mg. Kebutuhan vitamin C berdasar AKG 2013 adalah 75 mg dan 90 mg untuk perempuan dan laki-laki. Berbeda dengan asupan energi, protein, dan vitamin $\mathrm{C}$ yang kurang dari $\mathrm{AKG}$, asupan vitamin A pada kedua kelompok bahkan lebih dari
2 kali lipat AKG yaitu 1.313 dan $1.324 \mu \mathrm{g}$ dengan AKG vitamin A yaitu sebesar $600 \mu \mathrm{g}$ dan $500 \mu \mathrm{g}$.

\section{Perubahan kadar MDA setelah intervensi}

Kadar MDA sebelum perlakuan tidak berbeda pada kelompok yang diberi ekstrak teh hijau dan kelompok placebo $(p>0,05)$. Berdasarkan Tabel 3 diketahui bahwa pada akhir penelitian kelompok yang diberi perlakuan ekstrak teh hijau mengalami penurunan kadar MDA secara signifikan sedangkan kelompok placebo juga mengalami penurunan kadar MDA akan tetapi tidak signifikan. Namun demikian, perubahan kadar MDA tersebut tidak berbeda pada kedua kelompok.

\section{Perubahan performa fisik setelah intervensi}

Tabel 4 menunjukkan adanya kecenderungan penambahan kekuatan genggam tangan sebesar 0,28 kg pada kelompok yang mendapatkan ekstrak teh hijau, 
Tabel 2. Status gizi dan rerata asupan zat gizi pada awal penelitian

\begin{tabular}{|c|c|c|c|}
\hline Kondisi awal & $\begin{array}{c}\text { Ekstrak teh hijau } \\
(\mathrm{n}=\mathbf{2 8})\end{array}$ & $\begin{array}{c}\begin{array}{c}\text { Placebo } \\
(\mathrm{n}=29)\end{array} \\
\end{array}$ & $\mathbf{p}$ \\
\hline \multicolumn{4}{|l|}{ IMT (n,\%) } \\
\hline Gizi kurang & $6(21)$ & $4(14)$ & 0,459 \\
\hline Gizi normal & $17(61)$ & $16(55)$ & \\
\hline Overweight dan obesitas & $5(18)$ & $9(31)$ & \\
\hline \multicolumn{4}{|l|}{ Status Gizi (MNA) (n,\%) } \\
\hline Malnutrisi & $2(7)$ & $0(0)$ & 0,232 \\
\hline Risiko malnutrisi & $12(43)$ & $10(34)$ & \\
\hline Status gizi baik & $14(50)$ & $19(66)$ & \\
\hline Energi (kkal) & $1313,3 \pm 79,3$ & $1195,7 \pm 76,5$ & 0,290 \\
\hline Protein $(\mathrm{g})$ & $37,2 \pm 15,6$ & $34,8 \pm 11,8$ & 0,520 \\
\hline Vitamin A $(\mu \mathrm{g})$ & $1313,4 \pm 554,6$ & $1324,8 \pm 887,2$ & 0,954 \\
\hline Vitamin C (mg) & $31,7 \pm 16,2$ & $33,4 \pm 14,3$ & 0,670 \\
\hline \multicolumn{4}{|l|}{ Asupan teh hitam (n,\%) } \\
\hline$<4$ gelas & $25(89)$ & $28(97)$ & 0,283 \\
\hline$\geq 4$ gelas & $3(11)$ & $1(3)$ & \\
\hline
\end{tabular}

Tabel 3. Perbedaan kadar MDA antar perlakuan

\begin{tabular}{|c|c|c|c|c|}
\hline Perlakuan & $\begin{array}{l}\text { Sebelum } \\
(\mu \mathrm{mol} / \mathrm{L})\end{array}$ & $\begin{array}{c}\text { Setelah } \\
(\mu \mathrm{mol} / \mathrm{L})\end{array}$ & $\operatorname{Delta}(\Delta)^{2}$ & $\mathbf{p}^{3}$ \\
\hline Ekstrak teh hijau $(n=13)$ & $2,47 \pm 0,84$ & $1,93 \pm 0,77$ & $0,53 \pm 0,85$ & 0,04 \\
\hline Placebo $(n=17)$ & $2,85 \pm 0,83$ & $2,51 \pm 1,11$ & $0,33 \pm 0,77$ & 0,10 \\
\hline $\operatorname{Sig}(p)^{1}$ & 0,23 & 0,12 & 0,51 & \\
\hline
\end{tabular}

Data dinyatakan dalam rerata $\pm \mathrm{SD}$, nilai signifikansi (sig) $\mathrm{p}<0,05$

${ }^{1}$ Hasil analisis independent $t$-test antar kelompok perlakuan dalam kolom yang sama;

${ }^{2}$ Selisih antara rata-rata posttest dan pretest; ${ }^{3}$ Hasil analisis paired t-test dalam baris yang sama

Tabel 4. Perbedaan kekuatan genggam tangan antar perlakuan

\begin{tabular}{lcccc}
\hline \multicolumn{1}{c}{ Perlakuan } & $\begin{array}{c}\text { Sebelum } \\
(\mathbf{k g})\end{array}$ & $\begin{array}{c}\text { Setelah } \\
(\mathbf{k g})\end{array}$ & Delta $(\Delta)^{2)}$ & $\operatorname{Sig}(\mathbf{p})^{\mathbf{3})}$ \\
\hline Ekstrak teh hijau $(\mathrm{n}=28)$ & $16,37 \pm 6,27$ & $16,66 \pm 5,16$ & $0,28 \pm 4,13$ & 0,71 \\
Placebo (n=29) & $16,185 \pm 7,12$ & $15,60 \pm 7,47$ & $-0,57 \pm 4,80$ & 0,52 \\
Sig (p) ${ }^{1)}$ & 0,91 & 0,53 & 0,46 & \\
\hline
\end{tabular}

Data dinyatakan dalam rerata $\pm \mathrm{SD}$, nilai signifikansi ( $\mathrm{sig}) \mathrm{p}<0,05$

${ }^{1}$ Hasil analisis independent $t$-test antar kelompok perlakuan dalam kolom yang sama;

${ }^{2}$ Selisih antara rata-rata posttest dan pretest; ${ }^{3}$ Hasil analisis paired t-test dalam baris yang sama

meskipun penambahan tersebut tidak bermakna secara statistik. Sementara pada kelompok yang mendapat placebo tidak terjadi penambahan kekuatan genggam tangan, justru terjadi cenderung penurunan kekuatan genggam tangan.

\section{BAHASAN}

Berdasarkan analisis dapat diketahui bahwa pemberian ekstrak teh hijau dapat menurunkan kadar
MDA lansia. Penurunan ini terjadi karena kandungan senyawa polifenol berupa katekin pada ekstrak teh hijau yang dapat berperan sebagai antioksidan. Hasil penelitian ini sejalan dengan penelitian yang menyatakan bahwa pemberian ekstrak teh hijau yang mengandung 210 mg EGCG selama 4 minggu dapat menurunkan indikator stres oksidatif yang diukur dengan kadar MDA (11). Polifenol pada teh yang berupa katekin dapat berperan sebagai antioksidan melalui beberapa mekanisme, diantaranya dengan cara menangkap radikal 
dan oksidan. Antioksidan juga dapat melindungi sel dan jaringan dari kerusakan oksidatif $(18,19)$. Penelitian in vivo menunjukkan bahwa konsumsi teh hijau dapat meningkatkan aktivitas antioksidan, meningkatkan aktivitas superoksida dismutase dan ekspresi katalase di aorta (20,21). Enzim tersebut berfungsi untuk melindungi sel dari serangan radikal bebas $(21,22)$.

Kadar MDA mengalami penurunan baik pada kelompok placebo maupun kelompok intervensi. Penurunan kadar MDA yang terjadi pada kelompok placebo kemungkinan disebabkan oleh faktor lain yang tidak terukur dalam penelitian ini, seperti besarnya aktivitas fisik yang dilakukan dan antioksidan plasma dan asam askorbat di plasma. Berdasar penelitian yang telah dilakukan peneliti sebelumnya, diketahui bahwa kadar asam askorbat di plasma berbanding terbalik dengan kadar MDA (23). Kadar MDA juga dipengaruhi oleh besarnya aktivitas fisik yang dilakukan (24).

Lebih lanjut, hasil analisis juga menunjukkan bahwa pemberian ekstrak teh hijau dapat menghambat penurunan kekuatan genggam tangan. Kelompok yang mendapat ekstrak teh hijau menunjukkan kecenderungan peningkatan kekuatan genggam tangan sedangkan kelompok yang mendapat placebo menunjukkan kecenderungan penurunan kekuatan genggam tangan. Penelitian yang pernah dilakukan menyatakan bahwa terdapat hubungan antara konsumsi antioksidan dengan performa fisik lansia (19). Evaluasi keefektifan intervensi gizi dipengaruhi oleh banyak hal yang mempengaruhi kekuatan dan massa otot. Lama intervensi ekstrak teh hijau yang hanya empat minggu dimungkinkan belum bisa memberikan pengaruh pada perubahan kekuatan genggam tangan lansia secara signifikan, meskipun hingga saat ini belum ada ketetapan mengenai durasi intervensi untuk memaksimalkan manfaat dan meminimalkan risiko perlakuan.

Penelitian serupa pernah dilakukan pada tahun 2004 dengan pemberian suplemen selama 8 minggu pada lansia malnutrisi dan diikuti selama 24 minggu (25). Hasil menunjukkan terjadinya peningkatan kekuatan genggam tangan selama pemberian suplementasi. Akan tetapi, kekuatan genggam tangan ini semakin menurun setelah suplementasi dihentikan. Penelitian lain hanya menyebutkan bahwa waktu minimal yang diperlukan untuk melihat perubahan pada masa otot yaitu selama enam bulan (26).

Pada penelitian ini tidak diukur kadar antioksidan plasma setelah pemberian ekstrak teh hijau karena adanya keterbatasan biaya, padahal bioavailabilitas kandungan ekstrak teh hijau akan menentukan bioaktivitasnya (27). Bioavailabilitas asupan ekstak teh hijau salah satunya dipengaruhi pada saat proses penyerapan. Proses penyerapan EGCG salah satunya dipengaruhi oleh ketersediaan atau asupan vitamin C. Asupan vitamin $\mathrm{C}$ pada kedua kelompok masih jauh dari $\mathrm{AKG}$, yaitu hanya sekitar $30 \mathrm{mg}$. Asupan vitamin $\mathrm{C}$ yang rendah ini dimungkinkan mempengaruhi penyerapan katekin. Penyerapan EGCG akan maksimal jika dikonsumsi bersamaan dengan konsumsi vitamin C yang cukup (28). Faktor lain yang berpengaruh pada kadar EGCG plasma adalah kadar serum albumin subjek. Adanya keterbatasan biaya menyebabkan penelitian ini tidak bisa mengukur kadar albumin pada serum subjek. Berbagai literatur menyebutkan bahwa seiring dengan pertambahan usia, maka akan terjadi penurunan kadar albumin (29). Serum albumin berperan dalam transportasi EGCG. Kadar serum albumin yang rendah dapat menurunkan kadar EGCG di plasma (30).

\section{SIMPULAN DAN SARAN}

Pemberian ekstrak teh hijau dapat menurunkan kadar MDA secara signifikan serta dapat mencegah penurunan kekuatan genggam tangan. Namun, pemberian ekstrak teh hijau ini tidak berbeda signifikan dibanding placebo. Pada penelitian selanjutnya, perlu dilakukan pengkajian mengenai pengaruh pemberian ekstrak teh hijau terhadap stres oksidatif dan kekuatan genggam tangan dengan mempertimbangkan variasi dosis dan durasi perlakuan.

\section{UCAPAN TERIMAKASIH}

Penulis mengucapkan terimakasih kepada Fakultas Kedokteran UGM yang telah memberikan dana melalui hibah dana masyarakat sehingga penelitian ini dapat terlaksana. 


\section{Pernyataan konflik kepentingan}

Penulis menyatakan tidak ada konflik kepentingan dengan pihak-pihak yang terkait dalam penelitian ini.

\section{RUJUKAN}

1. BPS. Statistik Penduduk Lanjut Usia 2014. Jakarta: BPS; 2015.

2. Fried LP. Epidemiology of aging. Epidemiol Rev 2000;22:95-106.

3. Bartali B, Salvini S, Turrini A. Age and disability affect dietary intake. J Nutr 2003;133(9):2868-73.

4. Hurley BF. Age, gender, and muscular strength. J Gerontol A Biol Sci Med Sci 1995;50:41-4.

5. Cruz-Jentoft AJ, Baeyens JP, Bauer JM, Boirie Y, Cederholm T, Landi F. Sarcopenia: European consensus on definition and diagnosis: report of the European Working Group on Sarcopenia in older people. Age Ageing 2010;39(4):412-23.

6. De La Fuente M. Effects of antioxidants on immune system ageing. Eur J Clin Nutr 2002;56:S5-8.

7. Pansarasa O, Castagna L, Colombi B, Vecchiet J, Felzani G, Marzatico F. Age and sex differences in human skeletal muscle: role of reactive oxygen species. Free Radic Res 2000;33(3):287-93.

8. Nielsen F, Mikkelsen BB, Nielsen JB, Andersen HR, Grandjean P. Plasma malondialdehyde as biomarker for oxidative stress: reference interval and effects of life style factors. Clin Chem 1997;43(7):1209-14.

9. Tea Association of the USA. Tea fact sheet - 2014. [series online] 2014 [cited 2015 Nov 23]. Available from: URL: http://www.teausa.com/14655/tea-fact-sheet

10. Erba D, Riso P, Colombo A, Testolin G. Supplementation of Jurkat $\mathrm{T}$ cells with green tea extract decreases oxidative damage due to iron treatment. J Nutr 1999;129(12):2130-4.

11. Freese R, Basu S, Hietanen E, Nair J, Nakachi K, Bartsch $\mathrm{H}$, Mutanen M. Green tea extract decreases plasma malondialdehyde concentration but does not affect otehr indicators of oxidative stress, nitric oxide production, or hemostatic factors during a highlinoleic acid diet in healthy females. Eur J Nutr 1999;38(3):149-57.

12. Coimbra S, Castro E, Rocha-Pereira P, Rebelo I, Rocha S, Santos Silva A. The effect of green tea in oxidative stress. Clin Nutr 2006;25(5):790-6.

13. Tinahones FJ, Rubio MA, Garrido-Sa'nchez L, Ruiz C, Gordillo E, Cabrerizo L, Cardona F. Green tea reduces LDL oxidability and improves vascular function. J Am Coll Nutr 2008;27(2):209-13.
14. Gunawijaya, FA. Penentuan LD-50 ekstrak teh hijau pada mencit strain C3H. Maj Ilm Kedokteran USAKTI 1999;15(4):1645-50.

15. Cesari M, Pahor M, Bartali B, Cherubini A, Penninx BW, Ferrucci L, et al. Antioxidants and physical performance in elderly persons: the Invecchiare in Chianti (InCHIANTI) study. Am J Clin Nutr 2004;79(2):289-94.

16. Lemeshow S, Hosmer Jr DW, Stephen KL. Besar sampel dalam penelitian kesehatan. Yogyakarta: Gadjah Mada University Press; 1997.

17. Rosner B. Fundamentals of biostatistics, seventh edition. Boston: Brooks/Cole Cengage Learning; 2010.

18. Hollman PCH, Feskens EJM, Katan MB. Tea flavonols in cardiovascular disease and cancer epidemiology. Proc Soc Exp Biol Med 1999;220(4):198-202.

19. Frei B, Higdon JV. Antioxidant activity of tea polyphenols in vivo: evidence from animal studies. J Nutr 2003;133(10):3275S-84S.

20. Skrzydlewska E, Ostrowska J, Farbiszewski R, Michalak K. Protective effect of green tea against lipid peroxidation in the rat liver, blood serum and the brain. Phytomedicine 2002;9(3):232-8.

21. Yokozawa T, Nakagawa T, Kitani K. Antioxidative activity of green tea polyphenol in cholesterol-fed rats. J Agric Food Chem 2002;50(12):3549-52.

22. Negishi H, Xu JW, Ikeda K, Njelekela M, Nara Y, Yamori Y. Black and green tea polyphenols attenuate blood pressure increases in stroke-prone spontaneously hypertensive rats. J Nutr 2004;134(1):38-42

23. Block G, Dietrich M, Norkus EP, Morrow JD, Hudes M, Caan B, Packer L. Factors Associated with Oxidative Stress in Human Populations. Am J Epidemiol. 2002;156(3):274-85.

24. Nazarina, Christijani R, Sari YD. Faktor-faktor yang berhubungan dengan kadar malondialdehyde plasma pada penyandang diabetes mellitus tipe 2. Jurnal Gizi Klinik Indonesia 2013;9(3):139-46.

25. Edington J, Barnes R, Bryan F, Dupree E, Frost G, Hickson M. A prospective randomised controlled trial of nutritional supplementation in malnourished elderly in the community: clinical and health economic outcomes. Clin Nutr 2004;23(2):195-204.

26. Cesari M, Fielding RA, Pahor M, Goodpaster B, Hellerstein M, Abellan van Kan G. Biomarkers of sarcopenia in clinical trials. Recommendations from the International Working Group on sarcopenia. J Cachexia Sarcopenia Muscle 2012;3(3):181-90.

27. Holst B, Williamson G. Nutrients and phytochemicals: from bioavailability to bio efficacy beyond antioxidants. Curr Opin Biotechnol 2008;19(2):73-82. 
28. Gertz MA, Comenzo R, Falk RH, Fermand JP, Hazenberg BP, Sanchorawala V, et al. Definition of organ involvement and treatment response in immunoglobulin light chain amyloidosis (AL): a consensus opinion from the 10th International Symposium on Amyloid and Amyloidosis. Am J Hematol 2004;79(4):319-28.

29. Greenblat DJ. Reduced serum albumin concentration in the elderly: a report from the Boston Collaborative
Drug Surveillance Program. J Am Geriatr Soc 1979;27(1):20-2.

30. Ishii T, Ichikawa T, Minoda K, Kusaka K, Ito S, Nakayama $\mathrm{T}$, et al. Human serum albumin as an antioxidant in the oxidation of (-)-epigallocatechin gallate: participation of reversible covalent binding for interaction and stabilization. Biosci Biotechnol Biochem 2011;75(1):100-6. 